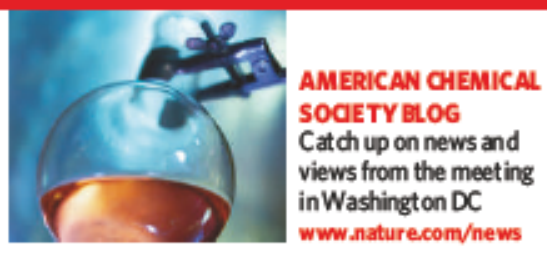

\title{
Governors take the initiative over US carbon dioxide emissions
}

Nine US northeastern states have set targets for cutting back on regional greenhouse-gas emissions.

The move is a rare step forward for the United States, which in 2001 refused to ratify the international Kyoto Protocol for regulating emissions. It seems that in the face of federal inaction, individual states have begun making their own dimate policy.

Under their plan, more than 600 power plants will cap their total carbon dioxide emissions at roughly 150 million tonnes - about what they emit now - starting in 2009. Between 2015 and 2020, they will cut back a further $10 \%$.

In an arrangement not unlike the European Union's carbon-trading scheme, power companies will be given - or perhaps sold the right to emit a certain amount of carbon dioxide. They may then sell credits if they cut emissions below that allocation.

"This is a big deal," says Judi Greenwald of the Pew Center on Global Climate Change in Washington DC, and an active participant in designing the policy. "It will be a really important policy experiment."

The plan comes from the two-year-old Regional Greenhouse Gas Initiative (RGGI), a coalition led by the governors of Connecticut, Delaware, Maine, Massachusetts, New Hampshire, New Jersey, New York, Rhode Island and Vermont. Together, the nine states emit as much carbon dioxide as Germany.

${ }^{\alpha}$ Many national programmes start out with the states as labs," says Richard Valentinetti, director of air-quality control for Vermont and an RGGI participant. "Since the national programme was being discussed to death and nothing was happening, we felt we had to do something."

State leaders for air-quality and energy issues say they are about a month away from a memorandum of understanding, a handshake agreement on their goals. That, in turn, will beget a 'model rule' that each state would have to adopt in order to trade emissions allocations. Supporters hope that the rules could be law two years from now.

The northeastern pact is the furthest along of several US regional climate-change initiatives. Washington, Oregon and California have

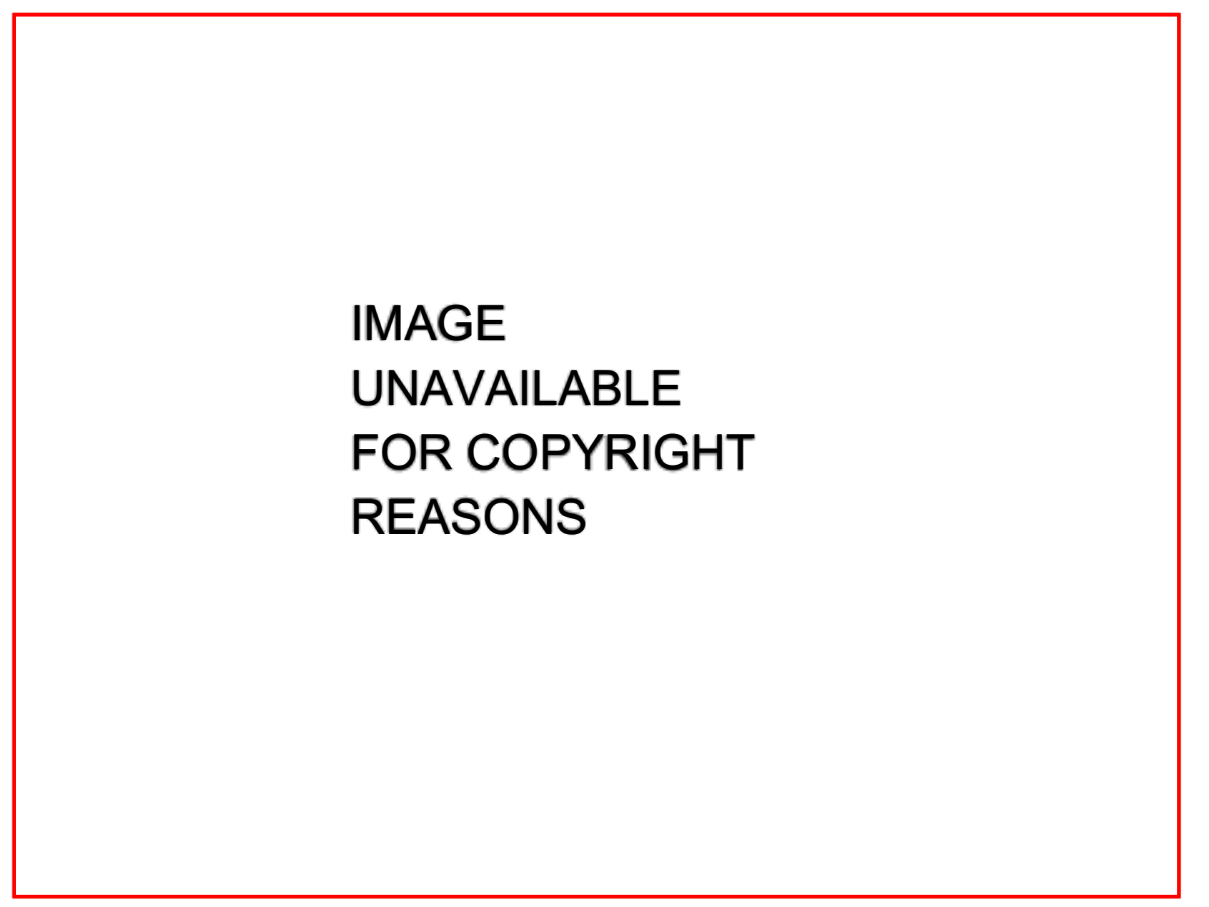

Clear approach: individual states are planning a system that resembles the EU carbon-trading scheme.

similarly joined together in the West Coast Governors' Global Warming Initiative. California has adopted tough emissions regulations on its own: in June, Governor Arnold Schwarzenegger mandated a return to 1990 emissions levels by 2020 , with a further reduction to $80 \%$ of 1990 levels by 2050 .

In the northeast, the RGGI decided to take action in part because of the possible regional impacts of climate change on the states. "Most of them are coastal states - they are worried about rising seas," says Greenwald.

Temperatures are also an issue for states dependent on tourism.

${ }^{\alpha}$ Maine is worried about its forest. Vermont is worried about its sugar maples," Greenwald explains.

Details of the RGGI plan are still under debate, with environmental and industry groups wrangling - as might be predicted. One bone of contention is 'offsets'. These are separate actions, such as planting trees or capturing landfill gases, that companies could take in lieu of reducing emissions. The current draft suggests that offsets could make up half the difference between projected and capped emissions, a number that some think is too high and others too low.

Cap-and-trade strategies have worked before in the United States, most notablyin the 1990s when they helped lower sulphur dioxide emissions from power plants, reducing acid rain. But capping and trading carbon dioxide is not so simple, given the politically charged atmosphere of climate-change discussions.

A regional solution for a global problem makes no sense, says Bill Fang of the Edison Electric Institute, a leading industry group based in Washington DC. He also argues that capping the power industry alone is unfair. "Why should we be singled out?" he asks. The RGGI plan, for instance, makes no mention of transport, the second largest source of carbon dioxide in the United States.

James Brooks, director of air quality for the state of Maine, says that the effort is more of a

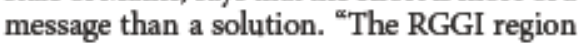
represents probably $3 \%$ of the world's greenhouse-gas emissions, so it is not going to have a huge impact," he says. "The idea is to set an example and to establish a working model that could be used nationally.

Emma Marris 